\title{
Genesis And Development Of Capital Market In CIS Countries: Cases From Russia, Kazakhstan, And Uzbekistan
}

\section{Otabek Narziev}

PhD in Law, Department of International private law, Tashkent state university of Law, Tashkent, Uzbekistan.

E-mail address: otabeknarziev@tsul.uz

\begin{abstract}
This paper provides the necessary information and analysis for understanding and considering the main research questions and discussions of the research. Notably, this section outlines the background to capital market formation and development in CIS countries through a brief history of the CIS; considers the necessity of capital market and its regulation in CIS countries; reviews the institutional and legal framework of capital market regulation, and analyzes certain problems of capital market development.
\end{abstract}

Keywords:

Capital market, capital market, CIS, transition economies, capital market legal regulation, Russia, Kazakhstan, Uzbekistan.

Article Received: 18 October 2020, Revised: 3 November 2020, Accepted: 24 December 2020

\section{Introduction}

This research attempts to analyze the transition reforms of certain Commonwealth of Independent States (CIS) members (namely, Russia, Kazakhstan, and Uzbekistan) and propose some recommendations on their further improvement. Chiefly, the present study focuses on developing one of the critical institutions of the market economy - namely, the capital market in terms of its role in promoting competitive conditions in the financial services sector. Due to various objective and subjective factors, banks have become the most dominant institutions in all CIS countries to accumulate and redistribute financial resources. In all of the countries examined in the present research, a considerable part of the banking sector is owned by the state that, consequently, enjoys several privileges that are not available to its competitors. One of the leading market institutions capable of competing with banks in the financial sector is the capital market. Still, despite almost three decades' worth of transitional reforms, the capital market remains underdeveloped across the CIS. As a result, companies, and investors are deprived of access to alternative and competitive business financing sources and have no option but to deal with the monopolized banking system in those countries.
Well-functioning capital markets enable and facilitate the mobilization of financial resources by bringing together those who need capital to innovate and grow with those who have the funds to invest. More importantly, capital markets promote good corporate governance amongst their listed issuers by encouraging transparency, accountability, and respect for shareholders' rights. The dramatic growth of stock exchanges from 50 to 160 in the last four decades alone demonstrates the vital role that capital markets play in developing economies. In the case of CIS members, it is essential not only to improve the understanding of the role and function of capital markets but also to create environments that ensure the development of wellfunctioning exchanges.

Based on above mentioned, this research examines capital market development in CIS members through enhancing its business financing capacity by balancing the regulatory framework of the existing banking sector with that of a functioning capital market; by diversifying the ownership structure of the market; and by implementing comprehensive legal reforms towards the further development of the market. 


\section{Materials and Methods}

This research has been conducted using literature review and publication research, comparative analysis and empirical study, and other techniques, including historical, qualitative, and quantitative research. The consequent thesis relies on data from the reports and reviews of IOSCO, the World Bank, the OECD, the EBRD, the IMF, the $\mathrm{ADB}$, and other international organizations and other specific research.

\section{Results}

The research's ultimate goal is to ultimately contribute to the development of a fair and functioning market economy in CIS countries through the improvement of their respective capital markets. The analysis assumes that complex legal and institutional reforms will serve the development of the capital market and its effects on inclusive economic growth in the region.

It would be too naïve to assume that CIS countries' capital markets would flourish like those of the UK or the US. We found that several factors directly affect the development of the capital market in CIS countries. The country's economic development level, the legal system, and social features are core issues to consider designing CIS countries' capital markets. Ensuring a balanced approach in banking and capital market regulation, equal treating SOEs and POEs, applying market transparency, and implementing free-market principles instead of administrative ones promote a real competition on business financing.

\section{Discussion}

\section{A market economy is a prerequisite for capital market origin in CIS}

The late 90s of the last century had a tremendous change in the world map. The collapse of the USSR and the emergence of newly independent states opened new pages in world history. These countries chose the market economy as the primary development way. The centrally planned economic model and the USSR's property structure left little room for the capital market's existence. Hence, during that period in CIS countries' territory, there were no market economy institutions, such as the capital market. The only financial instrument reminding capital market was the state bond. However, neither the issuance and circulation, nor the enforcement process of state bond was far from market economy principles. Instead, exclusively administrative methods used for the regulation of the economy, including the financial market. Therefore, from an institutional and functional viewpoint there was no economic or legal basis for the capital market and its regulation under centrally planned conditions.

Despite the same start of the transition, the reforms varied depending on each country's political, economic, social, geographical, and other features. Some states chose radical (or socalled shock therapy) methods of transition, while others opted for gradualist approaches.However, the method and content of the transition process, and conducted reforms, varied depending on each country's political, economic, social, geographical and other features. Some states chose radical (or so-called shock therapy) methods of transition, while others opted for gradualist approaches. For instance, Uzbekistan chose the gradual way of building a socially oriented market economy. According to some scholars, Uzbekistan transition approach mostly close to Chinese model of development, rather than of western models. While Russia and Kazakhstan at the first stage of transition had preferred a radical switch to a market economy, they subsequently sought to tune their policy.

The market-based economic models adopted thus provided the main cornerstones for the foundation of the capital market in CIS countries. Such cornerstones had included private property, which emerged as the result of small and large-scale privatizations; joint stock companies, which appeared as the consequence of securitization and company law reforms; and capital market infrastructure, which was the product of total transition reforms. Therefore, 
choosing market-based economic models and conducting transition reforms were the first steps that preceded capital market formation in CIS countries. The next steps concerned privatization and denationalization, which, established multiple forms of property rights including private ownership; reduced the level of state ownership; created joint stock companies; and eventually, formed capital markets as an indispensable part of the market economy. The nature of the emergent capital market in each CIS country mostly depended on the content and quality of privatization, company, and other, law reforms pursued in each state. That is why it is necessary to provide an overview of the initial stages of transition reforms in certain CIS countries to better understand the notion and specifications of their capital market regulation cornerstones.

\section{Features of Transition and privatization in CIS countries}

Restructuring and privatization- the processes of creating a feasible financial sector, reforming state enterprises, and transferring their ownership into private hands - is one of the main ingredients of the transition process. The phenomenon of privatization may be witnessed in the economic development history of most developed countries, for instance, Germany in the 1960s; Chile in the 1970s; the UK in the 1950s and again in the 1980s; the US in the 1980s; and Japan in the 1980-90s, all experienced privatization. After the Thatcher and Reagan reforms in the 1980 s in the UK and the US, respectively, privatization spread throughout the world, particularly in the post-soviet countries that started to emerge in the early 90s. Despite the initial western inspiration, privatization in post-soviet states, including the CIS, was further conditioned by their idiosyncrasies and special features which were formative on the development of the capital market infrastructure both at national and regional level. Key features of privatization in the postsoviet republics, including in CIS, include: the absence of market institutions; the absence of an entrepreneurial class; scarcity of investment resources; and the domination of large enterprises and/or state monopolies in the structure of the economy.

Privatization raises a range of ethical questions concerning how it may be socially unjust and unethical to privatize social and collective property, which had once been created and developed by the concerted efforts of several generations of the population under the previous economic model.

CIS countries faced different challenges from the first stages of transition due to their distinct economic, social, and geographical features, despite similarities concerning their common past, recent history, and economic structure. Several differences may be witnessed based on the speed and content of their respective privatization reforms that mostly relate to the features of their respective transition paths. For instance, in Uzbekistan privatization was incremental and through securitization. Russia experienced shock therapy and usage of the voucher scheme, and Kazakhstan had initially attempted shock therapy before amending its policy, and relying on coupons and securitization methods in its privatization reforms. Therefore, a brief review and comparison of the transition experiences of these countries may help one to better understand the characteristics of each transition, and of the cornerstones of CAPITAL MARKET formation in these countries specifically and the CIS region more generally.

\section{Russian transition puzzle and features of privatization in Russia}

Privatization in post-soviet countries including Russia - required the establishment of private property and the infrastructure to facilitate private ownership of previously state-owned property, which are fundamental to any economy claiming to be market-based. The Russian privatization experience was mostly characterized by high-speed reforms and radical changes which had fundamental economic, social, and political consequences. The Russian experience further contributed to the world history of privatizations with a seminal case study termed the "Russian 
transition puzzle" in the relevant literature.The main reason that the Russian experience has been considered unique and somewhat puzzling is the fact that it yielded inconsistent results with regard to the policy recommendation and forecasts that had previously been jointly proposed by the IMF, OECD, and EBRD in January 1991. In light of those recommendations, the following year Russia initiated sweeping mass privatization reforms, the main features of which could be observed in the speed and method of privatization.

Concerning the speed of privatization, Russia tried to implement rapid and radical changes equipped with the support of the IMF and of western countries. The immediate impact of shock therapy included record levels of price inflation and a dramatic drop in GDP. Consumer prices rose by $1,345 \%$ in the first year of shock therapy after August 1991. Price inflation was $896 \%$ in 1993, 220\% in 1994, 190\% in 1995 and as much as 48\% in 1996. Between 1992 and 1998, Russian GDP declined by $44 \%$, industrial production fell by $56 \%$, and capital investment by $80 \%$. By comparison, the fall in Soviet GDP during World War II had been 24\%. The reforms quickly met with resistance. Vested interests successfully pushed for the public financing of loss-making enterprises, and large-scale monetization of public sector deficits continued for several years.

All these results appealed to neoclassical economic theory to justify the overall direction of policy and led to several empirical research studies to analyze the reasons, consequences, and projections on Russian transition. For instance, Professor Jeffrey Sachs, a member of the group of western advisors concerning the first transition reforms in Russia, stated that structural implementation reasons, not shock therapy itself, as responsible for the failure of the Russian reforms. In the interview to the newspaper Novoye Vremya, Sachs mentioned that: "when we undertook the reforms we felt ourselves to be doctors who had been called to someone's sickbed. However, when we placed the patient on the operating table and opened him up, we found that his anatomical structure and internal organs were completely different, of a kind we never encountered in medical school". Other scholars linked the unsuccessful implementation of classical shock therapy in Russia mostly to Russian social and cultural particularities.For Joseph Stiglitz, the failure of rapid privatization in Russia "was not an accident, but a predictable consequence" of the absence of competition policies and the institutional and legal infrastructure needed to support successful reform efforts.Thus, the lack of experience, the peculiarities of the social structure that had evolved in Russia within the context of the planned economy system, as well as the choice of rapid privatization methods, all contributed to the emergence of certain drawbacks concerning the privatization process.

Another feature of the Russian transition experience that deserves attention is the method of privatization: the voucher scheme had been the main privatization method, by which every Russian citizen was given a privatization voucher worth 10,000 rubles that could be sold, exchanged for shares in privatized companies, or invested in collective investment vehicles known as 'voucher funds.' It would seem that rapid, top-down, and mass privatization was successfully under way. At least, such a conclusion could be drawn based on the initial results of privatization, which involved the privatization of 47,000 state-owned enterprises (SOEs) by 1993, and 90,000 a year later.However, a drawback of the voucher scheme is that it laid down the foundations for the advent and growth of financial pyramid schemes that soon spread not just across Russian territory, but also across all post-soviet countries, including the CIS region. Moreover, the voucher mechanicapital market presented opportunities for money laundering, and led to the concentration of ownership in the hands of former managers and civil servants who had previously been running most of the former SOEs and who by that point had thus become oligarchs.Western prescriptions, such as those of the IMF and of shock therapy advocates, allowed the former nomenclature and the financial 
'oligarchs' to acquire Russia's industrial and natural resources, and thus to heavily influence the country's political destiny.

A brief analysis of the Russian privatization experience allows one to draw the following conclusions: the privatization timeframe turned out to be extremely brief for solving such a grandiose task that determined the quality of privatization. Also, the ownership change did not entail an inflow of foreign investment, and the privatization was not accompanied by sufficient financial, legal and structural reorganization; a significant part of the property passed into the hands of persons closely associated with the criminal underworld and with the former party nomenclature. Despite the drawbacks discussed in the foregoing, Russian privatization reforms lay the foundations of the market economy; private property institutions; private owner and shareholder class; and of the capital market infrastructure in the country.

\section{Features of privatization in Kazakhstan}

The Kazakhstan experience concerning the formation of the private property system and the establishment of market economy institutions deserves particular attention due to the unique and distinctive features of the privatization model pursued. The main features are as follows: firstly, unlike Russia, Kazakstan developed its model of privatization based on the experience of former east bloc/soviet satellite countries including Poland, Hungary, and, what had been at the time, Czechoslovakia. Secondly, Kazakhstan initially appeared to follow a neoliberal path, but the government quickly assumed a prominent role once again.Thirdly, the lack of capable and robust institutions along with the dramatic economic reforms precipitated the failure of the neoliberal attempts in Kazakhstan. Fourthly, the privatization method used in Kazakhstan differs to those of the Russian and Uzbekistan privatization approaches. Fifthly, the privatization policies were associated with widespread corruption and a sense of casino or crony capitalicapital market similar to that which emerged in Russia between 1995-96. Lastly, unlike the experience of Russia and other
CIS countries, in Kazakhstan state-initiated public offerings were being sold mainly to strategic investors, rather than the public at large.

Below follows an analysis of the main reforms in order to gain a more precise picture of the Kazakhstan privatization experience and to draw the necessary conclusions for the subsequent research in the present thesis.

In 1991, the Supreme Council of the Kazakh Soviet Socialist Republic (SSR) adopted the resolution On the Main Directions of Denationalization and Privatization of State Property in the Kazakh SSR (of February 16, 1991) and the Law on Denationalization and Privatization (June 22, 1991). Legally, privatization was understood as the act of transferring state property to the ownership of physical and non-governmental legal entities. Later, the President of Kazakhstan approved the Program of Denationalization and Privatization of Property in the Kazakh SSR for 1991-1992 (Stage 1). The program provided for the mandatory privatization of a number of specific enterprises; and reserved the opportunity to privatize enterprises on the initiative of labor collectives with the provision of benefits to labor collectives. Auction, tender, or a joint-stock company were all approved vehicles of denationalization and privatization. The participation of foreign citizens and foreign legal entities in privatization was limited. At the initial stage of privatization, 4,770 entities, including 470 state farms, were withdrawn from state ownership.

The second stage of the privatization program was launched by Presidential Decree No. 1135 on March 5, 1993. It contained directions for the denationalization and privatization of the following: capital marketall-scale privatization of enterprises with up to 200 employees (sale at auctions and competitions); mass privatization of enterprises with a contingent of 200 to 500 employees (securitization); privatization of largescale enterprises and selected industrial projects with the participation of domestic and foreign investment. At this stage, privatization of significant and unconventional assets and 
enterprises was started under specific plans with the involvement of foreign legal entities and individuals.Such privatizations were carried out by: sales to individual investors on specified terms; auctions or tenders; open sale of shares; or the conclusion of concessions/management contracts.

The Kazakhstan privatization experience is mostly characterized by the implementation of the coupon mechanicapital market, which was different to the Russian voucher scheme. All citizens of Kazakhstan (including children) were to receive coupon books - residents of cities were credited with 100 coupons, and rural residents 120 to partially compensate for the difference in financial position.The scheme was designed in such a way that investment coupons were registered for their owners and were not subject to transfer or sale as unlike the case with the voucher privatization scheme in Russia. Coupons could only be invested in privatization investment funds (PIFs), which would issue their shares in exchange for coupons. PIFs, in turn, would purchase shares in SOEs at coupon auctions. As part of mass privatization, only privatization investment coupons were used as payment instruments.

Coupon privatization, the deadline for which had been shifted several times, was completed in February 1996. As a result of coupon privatization, investment funds ended up owning $10 \%$ of state property. At the same time, $66-68 \%$ coupons of the population were redeemed, i.e., one-third of the population did not use their coupons.

Unfortunately, the lack of time frames for reforming the economy led to ineffective solutions. The coupon method of privatization, based on the ideas of social justice, was not brought to completion as almost a third of the population did not use its coupons. Monetary privatization was not entirely focused on stimulating the real economy. 'As a result, the development of the economy was aimed at exporting raw materials -- this type of economic development is entirely reliant on the vagaries of the global commodity markets and is therefore very volatile. Despite the drawbacks of the principal privatization method used in Kazakhstan, the foundations of the market economy were laid by establishing private ownership, creating private owners and shareholders, and by providing the basis for the national capital market.

\section{The 'Uzbek Growth Puzzle' and features of privatization in Uzbekistan}

The main feature of privatization in Uzbekistan is characterized by its gradualist content concerning the so-called 'Uzbek Model' of transition that was based on five fundamental principles: full de-ideologization of the economy; the state is the main reformer; the rule of law; robust social protection; and the gradual formation of market relations. In the most populated country of the region, the prevention of a sharp fall in output, a reduction in people's incomes, and unemployment growth were the main reasons for opting for gradual privatization. Considering the special development path of Uzbekistan, Spechler mentions that the Uzbek government proclaimed that it would rather seek to emulate Japan and South Korea than the liberal Western economies. For instance, one of the main principles of Uzbekistan's transition to a market economy had been that 'the state is the main reformer'. This principle also could be seen in the case of Japan. According to Johnson, who has researched the 'Japanese miracle', "the Japanese state has served as a guide for economic development, e.g., through promoting technology transfer, planning the development of Japan's industrial structure and setting incentives to achieve the desired changes."Other scholars have also commented on the particularities of the Uzbekistan experience and its similarities to Japanese reforms in the 1950s-70s, South Korean reforms in the 1960s80s, and Chinese and ASEAN member reforms since the 1990s. Uzbekistan's growth performance during 1992-2001 was the best among those of the former Soviet republics. This fact is also recognized by the United Nations country study Assescapital marketent Report, 
according to which "by 2001 Uzbekistan's GDP was 3\% above the 1989 level, making the country's growth performance the best of the former Soviet Republics."

The Uzbek path to economic development has attracted the attention of many scholars and institutions for more than two decades. All of these studies recognized that tightly controlled, gradually reformed, Uzbekistan was the best performer among former Soviet republics.This was obvious, especially in the first decade of transition. In his paper entitled 'The Uzbek Growth Puzzle' Jeronim Zettelmeyer wondered why authoritarian and non-reformist Uzbekistan was doing better than other former Soviet Union countries, contrary to the expectations of major financial institutions. One of the most prominent scholars on Central Asian transition - namely, Professor Richard Pomfret - has also recognized Uzbekistan's GDP performance as being the best among other former Soviet countries, although he noted that the outcome in the second decade of transition has been less positive.Professor Terry McKinley has stated that "[y]et by any standard barometers of economic performance - as well as by comparison with other low-income countries Uzbekistan has been relatively successful over two decades of transition and development, though its achievements appear to remain a frustrating puzzle to many orthodox economists." As an example, Professor Popov cites the following figures: "[i]n 2013, Uzbekistan exported about 100 thousand cars, almost as much as Russia, whose GDP is 25 times larger" than Uzbek GDP.This relatively successful economic performance is even more impressive given that Uzbekistan is not a major oil and gas exporter (as is the case with Russia, Kazakhstan, Azerbaijan, and Turkmenistan) and given that it is one of two double-landlocked countries in the world.

Two decades after the EBRD Transition Report 2013 'Stuck in Transition?' identified a reverse 'puzzle' - namely, the Kyrgyz 'Puzzle' in that while Kyrgyzstan is applying almost all recommendations of the leading financial institutions its transition and economic growth seemed to have stalled. According to Islamov, "analyses of more than 20 years experiences of transition countries in Central Asia led us to the main conclusion that less radical and more gradual reforms resulted in better economic growth. In this respect, the achievements of Uzbekistan are not a "puzzle", but the logical result of its efforts to introduce gradually, step-by-step, market reforms combined with state-led industrial export-oriented policy, that was first successfully used in PostWorld War II Japan."

The gradual character of the Uzbekistan transition model directly reflected the speed of privatization reforms that were performed in four stages. The first stage (1992-1993) covered the state housing fund, capital marketall and medium enterprises of trade, service, light and food industries, by which 52,268 owners arose.The second stage (1994-1996) mostly focused on wide-scale privatization, based on which 2 million shareholders of privatized enterprises, 3 million owners of private household plots, 85,000 owners of individual and capital marketall enterprises, and 14,000 real estate owners arose. The third stage of privatization, which began in 1998, mostly focused on the privatization of industrial giants, such as oil, energy, chemical, metallurgical, and machine-building industries, with the extensive involvement of foreign investment.The fourth stage, which began from 2000 and remains ongoing, is characterized with the privatization of state assets through zero redemption cost; the intense attraction of FDI in the privatization process; and and better management of state shares.

Another feature of privatization - unlike the voucher scheme (that was used in Russia) and the coupon mechanicapital market (that was used in Kazakhstan) - was based on the securitization of state-owned enterprises. A further feature of Uzbek privatization involved the usage of zero redemption cost method, which, as stated earlier, involves the free transfer of state property to the new owner under appropriate investment obligations, such as the obligation to invest in new technologies, foreign currency; creation of 
employment positions in designated regions and so on.

The mass reorganization of state enterprises to joint-stock companies reached its peak after the adoption of Presidential Decree 'On Priorities for the Further Development of the Denationalization and Privatization Process in Uzbekistan'This decree specified the group of stakeholders in the open joint stock companies formed by privatization. These were the state, employers, foreign partners, and other investors.

Despite all of their achievements, Uzbekistan and other CIS countries are still facing severe challenges in developing their market institutions and strengthening market-based relations. According to the latest EBRD country asses capital market, although Uzbekistan continues to demonstrate strong growth, monopolization of power within the executive branch, state dominance of the economy, and the failure to establish a functionally independent judiciary, have all hindered Uzbekistan's transition process.Such a phenomenon is particularly evident in the financial market, including the capital market, its infrastructure, and regulation. Following the review of two decades of the transition experience of Uzbekistan, Professor Pomfret also highlights the severe financial repression and domination of the financial sector by state-owned banks.Another scholar specializing in the transition of post-Soviet countries - namely, Vladimir Popov -has predicting probable economic decrease and necessity for further reforms, recommends increasing the rate of accumulation by ten percentage points through the mobilization of domestic savings and attracting capital from abroad to avoid a decrease in growth.

As is the case with other CIS countries, processes in Uzbekistan created private property institution, shareholders, and joint stock companies that have raised the necessity for an organized capital market, which began through the development of the capital market infrastructure and the proper legal basis for such market.
As shown in the brief analysis of the privatization experience of CIS countries, primarily Russia, Kazakhstan, and Kyrgyzstan, despite their neoliberal approach, transition reforms will not bring expected results, if there is insufficient institutional and legal infrastructure. It is as if a camper were to attempt to burn a fire just with a spark without possessing kindling, firewood or any other proper fuel. In this regard, the capital market infrastructure will serve as a source for transferring the spark of privatization reforms to the fire of the current market relations and maintain its stability and growth that would enlighten and further heat the path to development.

\section{Conclusion}

In the foregoing, it has been attempted to outline the genesis, evolution, and development of the capital market in the CIS region, and to draw up key regional and some country-based specifics of the CIS embryonic capital market infrastructure and of its legal and regulatory framework. It was concluded that there were particular political, economic, and social bases for the emergence of the capital market and its infrastructure in these post-Soviet jurisdictions. Notably, the collapse of USSR, the formation of CIS, the choice of the market economy as the primary means of development, privatization, and the appearance of shares and JSCs all provided fertile ground for the genesis of basic capital market institutions in postSoviet territories. Despite the almost three decades of existence, these markets have yet to rid themselves of certain anomalies including their oligopolistic character, state and bank dominance, scarcity of professional institutions, opacity and modest corporate governance, and lack of investor confidence.

\section{References}

[1] "The Role of Stock Exchanges in Fostering Economic Growth and Sustainable Development", Joint publication by UNCTAD and the World Federation of Exchanges 
(WFE/UNCTAD/2017), September 7,

2017, 2,

https://unctad.org/en/PublicationsLibrary/ WFE_UNCTAD_2017_en.pdf

[2] Akhtamova Y. Protection of International Investments. Analysis of Certain Clauses in International Agreements. Uzbekistan Case Study //Analysis of Certain Clauses in International Agreements. Uzbekistan Case Study (March 25, 2016). - 2016.

[3] Akramov A. Prospectives Of Trust Management Of Property In Uzbekistan //The American Journal of Political Science Law and Criminology. - 2020. T. 2. - №. 11. - C. 143-150.

[4] Amangeldiev Batirlan Ramazanovich the leading researcher of the Economic Security Department of the Kazakhstan Institute of Strategic Studies under the President of the Republic of Kazakhstan http://bibliotekar.kz/suverennyi-

kazahstan-na-rubezhe-

tysjache/privatizacija-v-kazahstane.html

[5] Bakhtiyor Anvarovich Islamov, "25 Years of Transition Economies Research and Three

HUs”地域経済経営ネットワーク研究

センター年報 $=$ The Annals of Research

Center for Economic and Business

Networks 5 (2016): 85-87.

[6] Bakhtiyor Islamov and Doniyor Islamov. "The Central Asian States 20 Years After: The "Puzzles" of Systemic Transformation", Acta Slavica Iaponica 35 (2014): 109-134;

[7] Bernard Black, Reinier Kraakman, and Anna Tarassova, "Russian Privitization And Corporate Governance: What Went Wrong", Stan. L. Rev. 52 (1999):

[8] Bruce Kogut, and Andrew Spicer. "Capital Market Development And Mass Privatization Are Logical Contradictions: Lessons From Russia And The Czech Republic", Industrial and Corporate Change 11, no. 1 (2002): 1-37.
[9] Chalmers Johnson, MITI and the Japanese Miracle: the Growth of Industrial Policy: 1925-1975. (Stanford, California: Stanford University Press, 1982).

[10] Chris Edwards, "Margaret Thatcher's privatization legacy", Cato Journal 37 (2017): 89.

[11] Chrystia Freeland, Sale of the Century: Russia's Wild Ride from Communism to Capitalism. Crown, 2000;

[12] David E. Hoffman, The Oligarchs: Wealth and Power in the New Russia, (Hachette UK, 2011);

[13] David M. Kotz and Thompson Hall, "The "Uzbek growth puzzle" and the Washington Consensus", In A Session on 'Issues in Economic Transition' sponsored by the Union for Radical Political Economics at the Allied Social Science Associations Convention. 2004.

[14] Eurasian Development Bank Report, "The Capital markets of Russia and Kazakhstan: Prospects for Integration", Almaty, 2010, 12. http://www.eabr.org/eng/ publications/AnalyticalReports/

[15] Hiromi Tamamura, "The actual state and effect of privatization in Japan," In East Asia Competition Policy Forum. 2002, http://www.jftc.go.jp/eacpf/03/privatizatio n.pdf

[16] James Roaf, Ruben Atoyan, Bikas Joshi, and Krzysztof Krogulski. "25 Years of Transition." (2014).

[17] Jeffrey Sachs writing in Novoye Vremya (1995) No. 28, cited in Roy Medvedev, Post-Soviet Russia: A Journey through the Yeltsin Era (New York: Columbia University Press, 2000), 84.

[18] Jeromin Zettelmeyer, The Uzbek Growth Puzzle. No. 98-133, International Monetary Fund, 1998.

[19] Kathryn H. Anderson and Richard W. T. Pomfret, Consequences Of Creating A Market Economy: Evidence From Household Surveys In Central Asia, 
(Cheltenham, UK: Edward Elgar Publishing, 2003), 75.

[20] Katja Fuder, A Long Goodbye: Federal Industrial Entrepreneurship and Privatization Policy in Germany 19451989, December 3, 2012

[21] Marshall I. Goldman, Lost Opportunity: What has Made Economic Reform in Russia so Difficult (New York: WW Norton \& Company, 1996)

[22] Maxim Boycko, Andrei Shleifer, and Robert Vishny, Privatizing Russia, MIT Press, 1997; Vladimir Popov, "A Russian Puzzle: What Makes the Russian Economy Transformation a Special Case", (1996);

[23] Narziev, Otabek. "Problems and Prospects of Development Legal Bases of Stock Market Regulation in Uzbekistan"

[24] Narziev, Otabek. "Capital market Regulation Theories and Perspectives of their Improvement." Available at SSRN 3622883 (2020).

[25] Paul Khlebnikov, "Godfather of the Kremlin: Boris Berezovsky and the Looting of the Russian State", (2000);

[26] Peter Reddaway,and Dmitri Glinski, The Tragedy Of Russia's Reforms: Market Bolshevism Against Democracy, (Washington, DC: United States Institute of Peace Press, 2001).

[27] Richard Pomfret and Richard W T Pomfret, The Central Asian Economies Since Independence. (Princeton, NJ: Princeton University Press, 2006).

[28] Richard Pomfret and Richard W. T. Pomfret, The Central Asian Economies Since Independence, (Princeton, NJ: Princeton University Press, 2006), 6 http://press.princeton.edu/chapters/s8279. pdf

[29] Richard Pomfret, "Central Asia after two decades of independence", In Economies in Transition, 400-429. (London: Palgrave Macmillan, 2012).
[30] Richard Pomfret, The Economies of Central Asia. Vol. 318, (Princeton, NJ: Princeton University Press, 2014);

[31] Sadievich, Narziev Otabek. "Capital market Development in CIS Countries: Legislative and Regulatory Lessons from Kazakhstan, Russia, and Uzbekistan." PhD diss., 神戸大学, 2019.

[32] Simon Deakin and John Hamilton, "Russia's Legal Transitions: Marxist Theory, Neoclassical Economics and the Rule of Law" (2015), p.17.

[33] Stanley Fischer, cited in Peter Reddaway and Dmitri Glinski, The Tragedy of Russia's Reforms: Market Bolshevism Against Democracy (Washington, DC: United States Institute of Peace Press, 2001), 301.

[34] Terry McKinley, "The Puzzling Success of Uzbekistan's Heterodox Development", Development

Viewpoint 44 (2010): 15.

[35] Turdialiev M. A., Komilov B. The Legal Issues Of International Investment Activity In Uzbekistan: Critical Analysis And Legal Solutions //The American Journal of Political Science Law and Criminology. - 2020. - T. 2. - №. 12. C. 16-21.

[36] Ulugbek Olimov,and Yadgar Fayzullaev, "Assessing Development Strategies to achieve the MDGs in the Republic of Uzbekistan", United Nations Department for Social and Economic Affairs (2011): 1-55.

[37] Vladimir Popov and Anis Chowdhury. "What Uzbekistan Tells Us about Industrial Policy That We Did Not Know?" (2015);

[38] Vladimir Popov, "A Russian Puzzle: What Makes the Russian Economy Transformation a Special Case", World Institute for Development Economics Research Paper No. 29 (1996).

[39] Vladimir Popov, "An Economic Miracle in the Post-Soviet Space: How Uzbekistan 
Managed to Achieve What No Other Post-

Soviet State Has", MPRA Paper 48723 (2014).

[40] Vladimir Popov, “Can Uzbekistan's Economy Retain its High Growth Rate?" Scenarios of Economic Development in 2015, (2014) 30.

[41] Vladimir Popov, "Russia: Inconsistent Shock Therapy with Weakening Institutions" in Transition and Institutions: The Experience of Gradual and Late Reformers edited by Giovanni Andrea Cornia and Vladimir Popov WIDER Studies in Developmental Economics, United Nations University,(Oxford: Oxford University Press, 2001);

[42] Vladimir Popov, "Shock Therapy Versus Gradualism Reconsidered: Lessons From Transition Economies After 15 Years Of Reforms" Comparative Economic Studies 49, no. 1 (2007): 1-31;

[43] Гулямов С. С. проблемы корпоративного управления и перспективы развития законодательства У Узбекистана //Государство и право: проблемы и перспективы совершенствования. 2018. - C. 96-99.

[44] Есентугелов А. Экономика независимого Казахстана: история рыночных реформ, Под ред. К.К. Еженовой. - Алматы, 2008. - 356 с.

[45] Каренов Р.С. «20 лет экономического перехода в Казахстане и перспективы индустриально-инновационного

развития стран», Экономическое Развитие, Вестник КарГУ, 2011. http://articlekz.com/article/5594;

[46] Маманазаров С.Ш. Акциядорлик жамияти ижроия органи: бошқарув ва рахбарликни амалга оширишнинг хуқуқий асослари // Юрист ахборотномаси - Вестник юриста Lawyer herald. № 6 (2020), Б. 62-66.

[47] НАРЗИЕВ О.С. КАПИТАЛ БОЗОРИ БИЗНЕСНИ МОЛИЯЛАШНИНГ
МУҚОБИЛ МАНБАСИ СИФАТИДА //

Юрист ахборотномаси - Вестник юриста - Lawyer herald. № 6 (2020), Б. 37-44

[48] Суверенный Казахстан на рубеже тысячелетий, М.С. Ашимбаев (ответственный редактор), 2001. Available at: http://bibliotekar.kz/suverennyikazahstan-na-rubezhe-tysjache. 